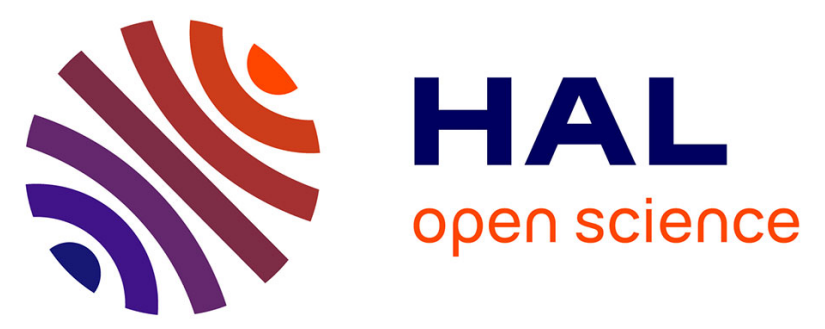

\title{
Autochthonous Japanese Encephalitis with Yellow Fever Coinfection in Africa
}

Etienne Simon-Loriere, Ousmane Faye, Matthieu Prot, Isabelle Casademont, Gamou Fall, Maria Fernandez-Garcia, Moussa M Diagne, Jean-Marie Kipela, Ibrahima Fall, Edward C Holmes, et al.

\section{To cite this version:}

Etienne Simon-Loriere, Ousmane Faye, Matthieu Prot, Isabelle Casademont, Gamou Fall, et al.. Autochthonous Japanese Encephalitis with Yellow Fever Coinfection in Africa. New England Journal of Medicine, 2017, 376 (15), pp.1483-1485. 10.1056/NEJMc1701600 . pasteur-02003897

\section{HAL Id: pasteur-02003897 \\ https://hal-pasteur.archives-ouvertes.fr/pasteur-02003897}

Submitted on 26 Apr 2019

HAL is a multi-disciplinary open access archive for the deposit and dissemination of scientific research documents, whether they are published or not. The documents may come from teaching and research institutions in France or abroad, or from public or private research centers.
L'archive ouverte pluridisciplinaire HAL, est destinée au dépôt et à la diffusion de documents scientifiques de niveau recherche, publiés ou non, émanant des établissements d'enseignement et de recherche français ou étrangers, des laboratoires publics ou privés.

\section{(1)(1) $\$(0)$}

Distributed under a Creative Commons Attribution - NonCommercial - ShareAlikel 4.0 
Authors: Etienne Simon-Loriere ${ }^{1,2,{ }^{*}}$, Ousmane Faye ${ }^{3}$, Matthieu Prot ${ }^{1,2}$, Isabelle Casademont ${ }^{1,2}$, Gamou Fall ${ }^{3}$, Maria Dolores Fernandez-Garcia ${ }^{3}$, Moussa Moise Diagne ${ }^{3}$, Jean-Marie Kipela ${ }^{4}$, Ibrahima Socé Fall ${ }^{5}$, Edward C. Holmes ${ }^{6}$, Anavaj Sakuntabhai ${ }^{1,2}$ and Amadou A. Sall ${ }^{3}$.

Affiliations:

1 Institut Pasteur, Functional Genetics of Infectious Diseases Unit, 75724 Paris Cedex 15, France.

2 CNRS URA3012, Paris 75015, France.

3 Institut Pasteur de Dakar, Arbovirus and Viral Hemorrhagic Fever Unit, BP220 Dakar, Senegal.

4 World Health Organization Country Representative Office, Luanda, Angola.

5 World Health Organization, Country Representative Office, Bamako, Mali.

6 Marie Bashir Institute for Infectious Diseases and Biosecurity, Charles Perkins Centre, School of Life and Environmental Sciences and Sydney Medical School, The University of Sydney, Sydney, NSW 2050, Australia.

To the Editor: Japanese encephalitis virus and yellow fever virus are mosquito-borne flaviviruses that circulate in disjunct geographic areas with different mosquito vectors. Japanese encephalitis is endemic to most of Asia and the Western Pacific, whereas yellow fever occurs in tropical areas of Africa and South America. Both viruses lead to a wide spectrum of disease severities that include asymptomatic infection and mild illness with influenza-like symptoms. However, severe yellow fever disease can be fatal in 20 to $60 \%$ of cases $^{1}$, whereas symptomatic Japanese encephalitis virus can progress to severe encephalitis, with case fatality rates of up to $30 \%$. Survivors often have long-term neuropsychological sequelae ${ }^{2}$. In March 2016, during the yellow fever outbreak in Angola, a 19-yearold man was admitted to the Cunene Provincial Hospital with a 5-day history of fever, headache, and jaundice. The patient, who survived, worked in the capital city of Luanda at the onset of disease and had not traveled abroad. A blood sample was obtained, and a test for yellow fever virus was positive. The sample was later processed for high-throughput RNA sequencing. Because the protocol followed made use of randomly primed cDNA synthesis, it provided a more complete and quantitative view of all RNA present in the sample than would have otherwise been possible, enabling the characterization of potential coinfecting viruses ${ }^{3}$. Surprisingly, de novo assembly of the sample revealed a Japanese encephalitis virus genome in addition to the expected yellow fever virus genome. Phylogenetic analysis revealed that this Japanese encephalitis virus variant belongs to genotype III, clustering closely with variants sampled in Asia (Fig. 1A, and Supplementary Appendix). The yellow fever virus sequence was closely related to both a sequence from the 1971 yellow fever virus outbreak in Angola and the recently reported yellow fever virus sequence detected in a sample from a Chinese traveler returning from Angola $^{4}$ (Fig. 1B).The likelihood of sample contamination is small, since neither the Institut Pasteur of Dakar, Senegal, where the RNA extracted from the samples in Angola was delivered, nor the laboratory at the Institut Pasteur, Paris, where the libraries were constructed and sequenced, has ever had any material containing Japanese encephalitis virus. In addition, none of the 15 additional RNA samples from patients with yellow fever virus who were treated at the same time provided reads that 
corresponded to Japanese encephalitis virus. Leftover sera from the Angola samples were later extracted at Institut Pasteur of Dakar, and only sample C17 was positive for Japanese encephalitis virus RT-qPCR. We found evidence of locally acquired infection with Japanese encephalitis virus in Africa in addition to coinfection with yellow fever virus, which raises the issue of the risk of circulation of the Japanese encephalitis virus and human infection in Africa. Since both the vectors and suitable hosts (e.g., pigs) for Japanese encephalitis virus are present in Angola, more studies of this virus in this locality, including serosurveillance, are needed. Increased levels of population movement between Asia and Africa may provide opportunities for pathogens to expand their geographic range. These data also highlight the potential usefulness of high-throughput sequencing, particularly untargeted approaches, for pathogen surveillance ${ }^{5}$.

\section{Figure legends}

Figure 1. Maximum likelihood phylogenetic trees of representative full-length (A) JEV and (B) YFV sequences. The isolates newly sequenced here are shown in bold, italic font. Viruses are identified by GenBank accession numbers, country of sampling and isolation date and viral genotypes are indicated. All horizontal branch lengths are scaled to the number of nucleotide substitutions per site and the trees were mid-point rooted for clarity only. Bootstrap values are shown for key nodes.

\section{References}

1. Monath TP, Vasconcelos PF. Yellow fever. J Clin Virol 2015;64:160-73. [PMID: 25453327]

2. WHO. Japanese Encephalitis Vaccines: WHO position paper - February 2015. Weekly epidemiological record 2015;90:69-87. http://www.who.int/entity/wer/2015/wer9009.pdf?ua=1

3. Matranga $C B$, Andersen KG, Winnicki $S$, et al. Enhanced methods for unbiased deep sequencing of Lassa and Ebola RNA viruses from clinical and biological samples. Genome Biol 2014;15:519. [PMID: 25403361]

4. Chen Z, Liu L, Lv Y, et al. A fatal yellow fever virus infection in China: description and lessons. Emerg Microbes Infect 2016;5:e69. [PMID: 27406389]

5. Gardy J, Loman NJ, Rambaut A. Real-time digital pathogen surveillance - the time is now. Genome Biol 2015;16:155. [PMID: 27391693] 
A

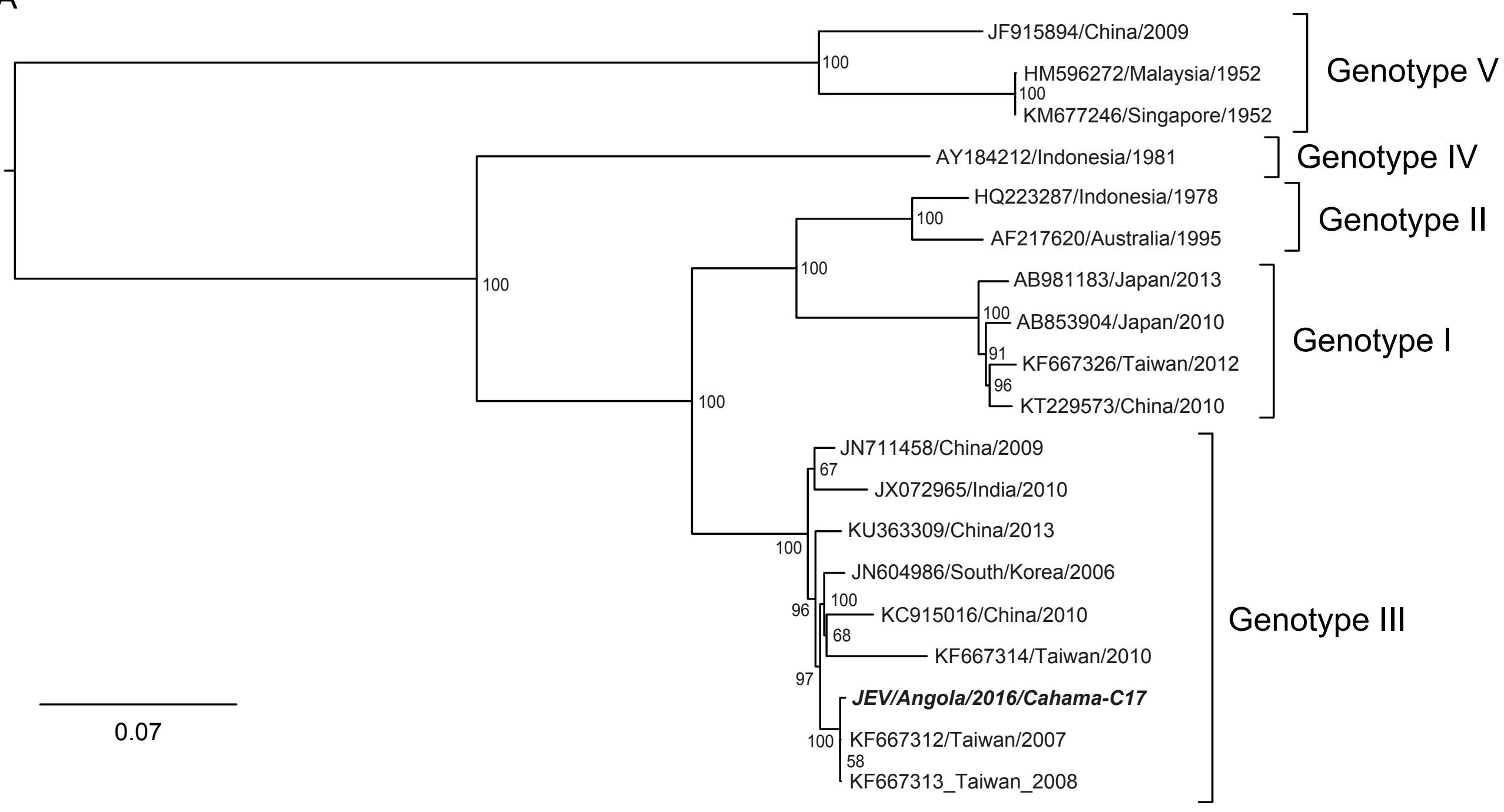

B

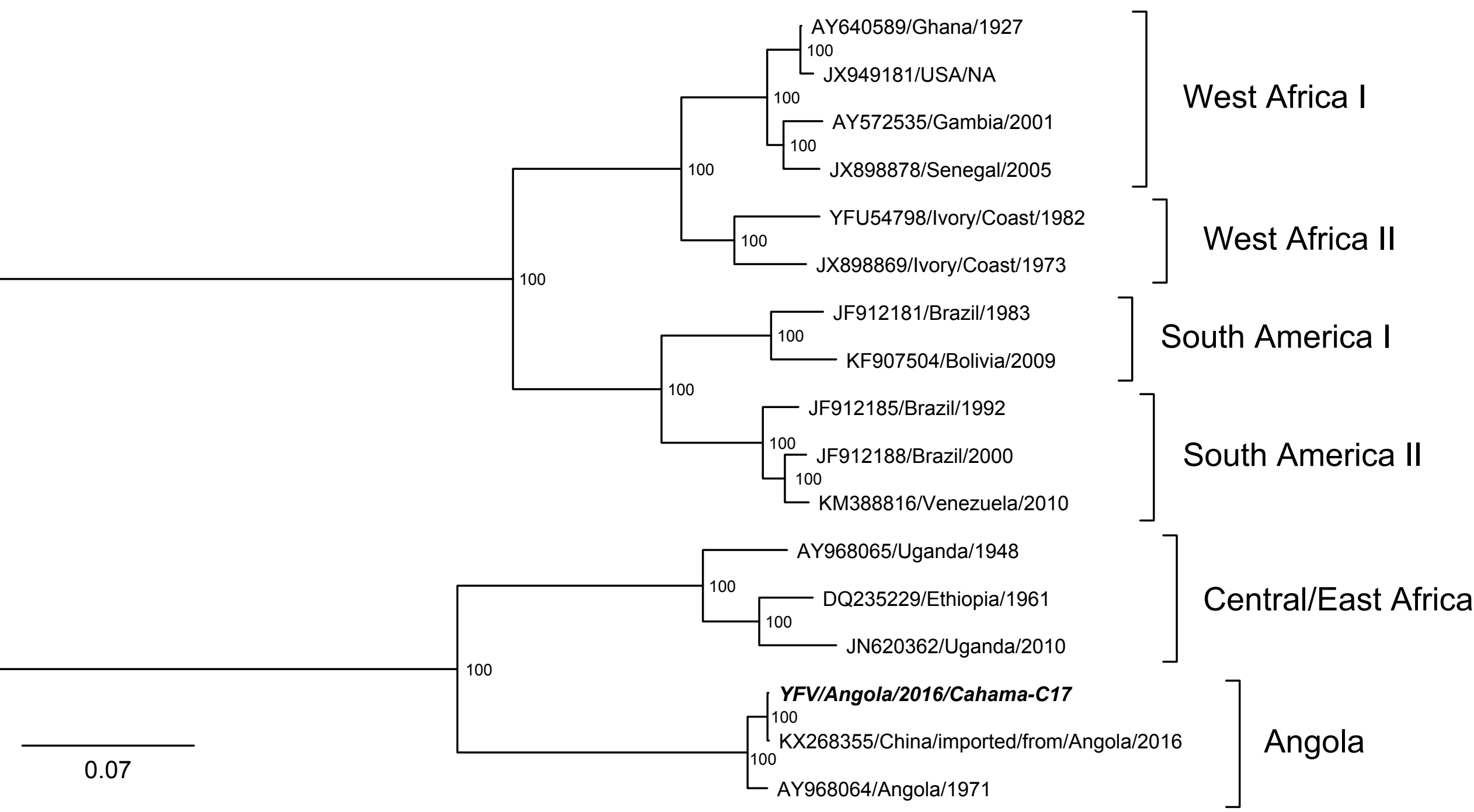

